Pachi, D. \& Barrett, M. (2012). Perceived effectiveness of conventional, non-conventional and civic forms of participation among minority and majority youth. Human Affairs, 22, 345359.

\title{
Perceived effectiveness of conventional, non-conventional and civic forms of participation among minority and majority youth
}

\author{
Dimitra Pachi and Martyn Barrett \\ Department of Psychology \\ University of Surrey, UK
}

Acknowledgement: The research reported in this paper was supported by a grant received from the European Commission 7th Framework Programme, FP7-SSH-2007-1, Grant Agreement no: 225282, Processes Influencing Democratic Ownership and Participation $(P I D O P)$ awarded to the University of Surrey (UK), University of Liège (Belgium), Masaryk University (Czech Republic), University of Jena (Germany), University of Bologna (Italy), University of Porto (Portugal), Örebro University (Sweden), Ankara University (Turkey) and Queen's University Belfast (UK).

Address for correspondence: Dr. Dimitra Pachi, Department of Psychology, University of Surrey, Guildford, Surrey GU2 7XH, UK; email: Dimitra.Pahis@surrey.ac.uk 


\begin{abstract}
The existing literature on political and civic participation has tended to neglect individuals' judgements about the effectiveness of specific forms of participation, focusing instead on the role of internal, external and collective efficacy in driving levels of participation. The present study examined young people's judgements of the effectiveness of specific forms of conventional, non-conventional and civic participation and the reasons which are given for these judgements. Fourteen focus groups were conducted with English, Bangladeshi and Congolese young people aged between 16 and 26 years old living in Greater London. The findings revealed differences in judgements of the effectiveness of action across ethnic groups, and differences in the specific reasons that are given for judgements of effectiveness as a function of ethnicity, gender and age. It is argued that greater attention needs to be paid to subgroups formed by the intersection of ethnicity, gender and age in order to understand young people's participatory attitudes and behaviours.
\end{abstract}




\section{Perceived effectiveness of conventional, non-conventional and civic forms of participation among minority and majority youth}

This paper reports a study which was conducted in London to investigate young people's judgements of the effectiveness of specific forms of political and civic action. The study also examined the reasons which these individuals gave for their judgements, and compared the judgements and reasoning given by the members of the national majority group (i.e., English youth) and two ethnic minority groups (Bangladeshi and Congolese youth). The perceived effectiveness of specific forms of political and civic action is an important topic to study, because the perceived effectiveness of a particular form of action is likely to be a significant predictor of an individual's willingness to undertake that action.

Over the past 20 years, youth political and civic participation has been the subject of a rich literature across different disciplines, including psychology, sociology, education and political science (e.g., Torney-Purta, Lehmann, Oswald \& Schulz, 2001; O’Toole, Lister, Marsh, Jones \& McDonagh, 2003; Zukin, Keeter, Andolina, Jenkins \& Delli Carpini, 2006). Levels and quality of participation have been extensively studied in relationship to political interest, political knowledge, internal and external efficacy, motivations, intentions, etc. However, less attention has been given to young people's judgements about the effectiveness or ineffectiveness of different forms of political and civic participation and the reasons which they give for these judgements.

In this paper, we specifically explore young people's perceptions of the effectiveness of conventional, non-conventional and civic forms of participation. The terms 'conventional' and 'non-conventional' participation are used here to denote different forms of political behaviour which are intended to influence governance either directly by affecting the making or implementation of public policy or indirectly by influencing the selection of individuals who make that policy (definition adapted from Verba, Schlozman \& Brady, 1995), with conventional activity involving electoral processes (e.g., voting, election campaigning, etc.) and non-conventional activity occurring outside electoral processes (e.g., signing petitions, participating in political demonstrations, etc.). The term 'civic' participation is used instead to denote voluntary activity which is focused on helping others, achieving a public good or solving a community problem (definition adapted from Zukin et al., 2006) (e.g., raising money for charity, helping neighbours, community volunteering, etc.).

Youth political and civic participation has now been examined using a range of both qualitative and quantitative methodologies (Stepick \& Stepick, 2002; Jensen \& Flanagan, 
2008; Simon \& Ruhs, 2008; Brooks, 2009). Despite these different methodologies, many studies over the last 10-15 years have reached the same conclusion: today's youth is neither apathetic nor disengaged. Although national records (of electoral registrations and voter turnout) show an unquestionable decline in the use of conventional forms of participation, there has been no decline in the use of non-conventional (signing petitions, demonstrating), technology based (internet social networks) and creative (artistic) forms of participation (O’Toole et al., 2010; Zukin et al., 2006). Similarly, while young people show less awareness of, less interest in and less knowledge of formal politics than previous generations did at the same age, they exhibit unrelenting interest in the well-being of the social groups to which they belong, both nationally and transnationally, and also in issues such as trans/national justice, trans/national equality, trans/national poverty and protection of the environment (Pachi \& Barrett, 2011). These are all issues that many young people do not consider to be 'political', due to the narrow image they have of politics which they associate only with elections, political parties and partisanship, and the negative image they hold of the political world as a network of corrupt, hypocritical, boring, rich and powerful people (Zukin et al., 2006). However, all of these issues are strongly political and have political implications.

Compared with research on participation by ethnic majority individuals, research on participation by ethnic minority individuals has been relatively recent and is not extensive, but has revealed that such populations are no less active than majority populations although the forms of participation in which minority individuals engage may be different in that they may focus particularly on issues affecting the minority ethnic group (Jensen, 2010; Seif, 2010; Stepick \& Stepick, 2002; Stepick, Stepick \& Labissiere, 2008). These studies have shown the importance of education, language proficiency and income (Wu, 2003), social trust, social links and culture (Fennema \& Tillie, 2001) and the prevailing political opportunity structure (Ahmad \& Pinnock, 2007; Penninx, Martiniello \& Vertovec, 2004) for participation by minority individuals.

The present study examined the judgements made by minority and majority youth about the effectiveness of conventional, non-conventional and civic forms of participation, and the reasons which they give for these judgements. There are many reasons that could potentially drive young people's judgements about the effectiveness or ineffectiveness of particular participatory behaviours. For example, a particular form of participation might be viewed as ineffective because an individual: (a) has low levels of trust in the institutions which are being targeted by the action; (b) feels that government, politicians or public official are generally unresponsive to citizens' views; (c) believes that civic and political systems only 
respond to large-scale social movements and discount individual actions; or (d) feels that the political system is biased and unfair.

Judgements about the effectiveness or ineffectiveness of a particular form of action are likely to drive whether or not an individual undertakes that action. Indeed, a number of authors (e.g., Klandermans, 1984; Simon et al., 1998) have argued that decisions about whether or not to participate are based directly on judgements concerning the likelihood that the participatory actions will actually achieve their intended goals, and perceived effectiveness has been found to be a strong predictor of all forms of participation (Zani, Cicognani \& Albanesi, 2012). It is therefore important to understand the reasons underlying people's judgements about the effectiveness of different forms of action.

Previous studies into political efficacy (e.g., Craig, Niemi \& Silver, 1990; Delli Carpini \& Keeter, 1996; Klandermans, 2002; Schulz, 2005; van Zomeren, Postmes \& Spears, 2008) have tended to focus on internal efficacy (i.e., the belief that one understands and is able to participate in the political sphere), external efficacy (i.e., the belief that public officials, politicians and institutions are responsive to citizens' demands) and collective efficacy (i.e. the belief that a collectivity or group is able to bring about political change if they work together). Klandermans' (1984) mobilization theory implies that there is a direct link between collective efficacy, perceptions of effectiveness and action. According to this theory, people's participation is a function of three cognitively based expectations: "a. expectations about the number of participants, b. expectations about one's own contribution to the probability of success and c. expectations about the probability of success if many people participate" (p.585). All three motivations are based on the evaluation of selective costs and benefits of one's participation and their values. It is argued, and empirically confirmed, that it is not enough just to believe in and to support the goals of a social movement in order to join the movement; people also have to believe that their participation will contribute to the achievement of the goals of the movement. Klandermans did not elaborate on the psychological factors and processes which might affect the perception that one's participation in a movement will contribute to the achievement of the goals of the movement; we believe that perceived effectiveness of the means used to achieve the goals of the action could be one of these factors. We would further argue that similar considerations must also underpin the perception of individual action (not only collective action), with the perceived effectiveness of individual action once again being an important driver of whether or not it is undertaken.

The present study addressed this gap in the literature, by examining the reasons which are given by minority and majority young people for their judgements about the effectiveness 
or ineffectiveness of different conventional, non-conventional and civic forms of participation. Given the differences which are known to occur in the political and civic behaviours of minority vs. majority populations, and the previous finding that minority individuals tend to focus particularly on issues and forms of action relevant to their own minority ethnic group (Jensen, 2010; Seif, 2010; Stepick \& Stepick, 2002; Stepick et al., 2008), it was expected that there would be differences in the judgements and reasoning of majority vs. minority participants, and that different judgements and reasons might be given by the members of different minority ethnic groups.

\section{Method}

All participants were recruited using a snowball technique. Younger Bangladeshi, Congolese and English participants (16-17 years old) were recruited through schools, youth centres, weekend community schools, religious organisations and scout associations in the area of Greater London, while the adult participants (18-26 years old) of all ethnic groups were recruited through the University of Surrey and through community and religious organisations in London. Fourteen focus groups were conducted in Greater London, to examine young Bangladeshi (4 groups), young Congolese (5 groups) and young English (5 groups) people's perceptions of political and civic participation. The focus groups were conducted in youth centres, local ethnically-based organisations and religious organisations. Separate focus groups were usually conducted with girls and boys for cultural and practical reasons. Separate groups were also conducted with those aged below voting age (16-17 years old) and those above voting age (18-26 years old). All focus groups were moderated either by the first author or by a fellow researcher working on the research project, and were conducted in English. They all lasted approximately one hour, and were recorded with participants' agreement. In total, 86 young people participated in these focus groups, with an equal number of girls and boys. Each group always contained no fewer than five participants.

The topic guide that was used to direct the focus group discussions aimed to elicit discussions of a wide range of issues concerning youth civic and political participation. Issues that were discussed included: participants' understandings of citizenship; their perceptions of young people's patterns of participation; their personal and group experiences of participation; their motivations for participating and their perceptions of the barriers to their participation; their perceptions of the effectiveness of different forms of participation; their perceptions of young people's information sources and influences; and their proposals for 
promoting inclusion and civic and political participation. The present paper only reports the findings relating to their perceptions of the effectiveness of different forms of participation.

The focus group discussions were transcribed and analysed following the principles of thematic analysis (Joffe \& Yardley, 2004; Braun \& Clarke, 2006). Both semantic and latent themes were identified in the data (Joffe \& Yardley, 2004) and analysed after repeated readings. In this process, first categories were generated based on the elements of the data relevant to the present study, and then these were combined into themes (Braun \& Clarke, 2006).

\section{Results}

The themes which emerged from the analysis are presented here for each ethnic group individually in turn, as it was hypothesised that the judgements and reasoning of participants from the three ethnic groups would be specific to each group.

\section{Bangladeshi participants}

Forms of conventional political participation such as voting were largely seen as being ineffective by the Bangladeshi participants, and the main factor that they used to explain this ineffectiveness was their low external efficacy. Perceptions of a lack of responsiveness and interest by politicians in people's views at grassroots level, as well as lack of efficacy of the voting/electoral system, deterred many of them from using conventional forms of participation:

\section{Participant 2}

I don't intend to register, I think it's a waste of time, I think it doesn't matter who you vote for, it's already done and dusted, they have already picked who they are gonna pick, it's, I think, but I believe that the government doesn't care about anything or anyone, they are gonna do what they are gonna do regardless, they went to the war on Iraq, that was one example, and as many examples, I personally feel it doesn't matter.

Interviewer

OK, what about you?

Participant 3

Yeah, I agree with the brother here, yeah. 
Perceptions of the ineffectiveness of particular actions were also related to beliefs about the lack of visibility of opportunities and the lack of a variety of opportunities in the political system for addressing young people's interests and skills. Both of these factors deterred the Bangladeshi youth from seeing the effectiveness of conventional forms of participation:

There aren't enough different opportunities, there's like, you can write to your MP, or you can join youth parliament. But then only a certain number of people are interested in this sort...these sorts of things. Loads of other young people, like to express themselves differently and I don't think there is enough, different varieties, there isn't enough variety for expression.

(British Bangladeshi female, over 18 years old, East London)

However, for some individuals, perceptions of the effectiveness of some forms of participation were associated with making oneself heard: using official channels to express one's views, keeping up the effort for a long period of time, targeting the correct people who can have an influence:

Me it would be councillors, MPs, get up the whole hierarchical system and get yourself heard, wherever it's, obviously even if you are doing over a period a time, get groups together, I mean that gets more noticed than it does doing something...

(British Bangladeshi female, under 18 years old, central London)

As far as non-conventional forms of participation such as graffiting and demonstrations were concerned, these were largely rejected by the female Bangladeshi participants and by the male Bangladeshi participants above voting age on the grounds of their ineffectiveness. Females below voting age and males above voting age attributed the ineffectiveness of these types of participation to the fact that they involved breaking the law. For females above voting age, their ineffectiveness was related to their low external efficacy and people's dislike of violence: 
...if you are graffiting then they are not gonna want to listen to you because you are doing something against the law, you are doing something against them, you are not really asking them to do something, they will just try to not do it because.... you are showing it in the wrong way.

(British Bangladeshi female under 18 years old, East London)

One of the extreme ones, probably demonstration... but demonstration isn't always like something I would agree with, because most people don't really like it cos it causes violence on the street.

(British Bangladeshi female, over 18 years old, East London)

However, female participants did view the effectiveness of non-conventional forms of participation as being affected by the scale of the action: action targeted at local issues was considered effective as well as action taken by considerable numbers of people. There was a belief that 'power is in numbers' and that the authorities pay attention to collective rather than individual claims, because they represent bigger groups in society:

\section{Participant 1}

Because they want to know everyone's opinion, they don't just want to know one person's, that's why people do petitions and stuff because they are not gonna listen to one person, they need a whole community, say do you know what? This is wrong, and you need to fix it.... and you know, just to listen to us.

Interviewer1

OK, do you agree with that?

Participant 3

More voices are heard.

\section{Participant 6}

One thing I would do, if I felt strongly about something is find other people who feel the same way that I do and then with them get their ideas as well and try to do something together.

(Bangladeshi girls, under 18 years old, central London) 
For male participants, the effectiveness of non-conventional forms of participation was related to the seriousness or importance of the issue for people and also to the record of proven effectiveness of these forms of action historically:

definitely not, but the suffragettes they starved themselves in order to get the vote for women...

(British Bangladeshi male, over 18 years old, central London)

there is some countries where you can't do nothing... you known them countries where they blow themselves up...I wouldn't do that but I am saying they do have reasons to do it, they are not doing it for no reason...

(British Bangladeshi male, over 18 years old, central London)

Older participants (both male and female) drew a distinction between the lack of effectiveness of non-conventional action and the need to express one's beliefs; this was supported by arguments that perceptions of ineffectiveness are shared even by groups that are politically and civically active:

That's the other side, it's not even to change, it's just to show our opinion that we are against this..... I don't believe that anyone believes that they are effective, personally I don't believe that anyone, even many Islamic groups like that are around when they do it, I don't think they do it because they believe they will change anything, I think they do it so that they are just removing the burden from them to say at least we tried to stand against this, not that we believe we are gonna change it.

(British Bangladeshi male, over 18 years old, East London)

Civic forms of participation were also discussed in the focus groups. Trust in the process through which charity money was managed was strongly associated with perceptions of the effectiveness of civic participation through charitable organisations. A belief in the honest management of charity money was associated with perceptions of effectiveness, while lack of knowledge of or suspicion about the way money is managed was associated with perceptions of ineffectiveness: 


\section{Participant 6}

We don't know where the money goes to...

Participant 4

Charity? We don't know where they are going.

(laugh)

Participant 1

To their back pocket.

(British Bangladeshi males, under 18 years old, central London)

\section{Interviewer1}

OK, do you think that these groups, as we said Oxfam or other charity groups, like Greenpeace or youth centres, do you think they can bring change?

(silence)

\section{Participant 4}

Yeah, they work to bring change, because they donate this and donate for...yeah... so yeah hopefully poverty...

( British Bangladeshi female, under 18 years old, central London)

British Bangladeshi participants above voting age in particular related the effectiveness of civic participation locally, nationally and internationally to good organisation and

\section{explanation of one's cause:}

\section{Participant 3}

I think, they have been an organisation working with the local people, they have made a big change, they went abroad to do charity group, I don't know, they went to this African country and did AIDS work, so getting involved with the local community can go out there and do something big.

\section{Participant 2}

That's true, if you organise well you can do.

(British Bangladeshi males, over 18 years old, East London)

If you get properly involved, I mean groups like Greenpeace cos it has to got to do with the environment... if it's say a country, if it's a country or an area you wanna save, if you get 
everyone involved, telling them why it is you wanna save it... whether it's down, like the coral reef...that's one big topic, everyone can argue, they can always protect it because they just spread the word...they just tell them how it is, how the natural beauty is...you can't destroy it and if everyone gets involved and understands why it's gonna be destroyed...

(British Bangladeshi male, over 18 years old, central London)

Perceptions of the effectiveness of civic participation were also associated with perceptions of personal enrichment. Participants who had participated in civic organisations felt they had become more aware of social issues, which in turn was associated with a belief in the effectiveness of this form of civic participation:

It's called, the organisation is called City Gate raid and the centre school Lansbury lodge so, I didn't know about it and in my private close, my next door neighbour went there for just volunteering as well and there was a crèche there for her children, so she kind of told me about it, and I went there, participated and I learnt so much about women's rights, cause it was about, it's all about women's workshops and everything, so it does, like community centres benefit a lot.

(British Bangladeshi female, over 18 years old, central London)

\section{Congolese participants}

The Congolese participants' perceptions of the ineffectiveness of conventional forms of participation, like those of the Bangladeshi participants, were strongly related to low external efficacy, that is, the belief that politicians and the political system are unresponsive to citizens' views. A distinctive feature of the Congolese participants' beliefs, however, was a perception of the lack of representativeness of the electoral/voting system:

I don't think voting makes a difference... Cos in 2005, Labour got $35.2 \%$ of the votes, $66 \%$ of people voted... $26 \%$ of the whole population actually wanted Labour... doesn't make a difference.... It's really the tyranny of the minority if enough people can come together and vote Labour, then Labour would come in... but I don't think politics works, I don't think governments work... I go there and really waste my time voting... I don't think anything really changes...

(Congolese female, over 18 years old, outer East London) 
In addition, for the Congolese participants, perceptions of the ineffectiveness of conventional participation were also linked to the reproduction of unequal power structures in Britain, mainly through the role of an 'elitist' education system acting as a gatekeeper of access to power. Congolese youth thought that since the majority of political candidates share the same class and educational background, power always stays within the same networks of people, leaving a lack of political alternatives for the citizens at the time of elections:

I think so yeah. Because if you looked at politicians those in power, they all come from the same families... I was observing British society and there is a strong problem with class. In Britain if you look at politicians and all that. Lots of Lords and kids of Lords... and they all come from the same kind of universities, Oxford and Cambridge, and private schools. To go to private school you need to spend $£ 10,000$ a year to educate your child...People with the same kind of social class would take the power and reproduce it again and again... In Britain most people don't care cos they get along with their lives, but for young people we need to change things. They make you believe by elections and all that 'oh yeah go and vote for him'... but to whom am I gonna vote for? Brown who has been discredited or Cameron who is the cousin of the Queen. It's a joke, we know it's a joke, we know we are wasting our time and they just killing each other...and yeah 'your vote counts', your vote doesn't count...

(Congolese male, over 18 years old, outer East London)

As far as forms of non-conventional participation are concerned, demonstrating and going on strike were both seen as ineffective by the Congolese participants due to their low external efficacy, the fact that politicians were non-responsive and uninterested in issues concerning young people:

If it makes them feel better then go ahead! I don't think it changes nothing when people protest ...

(Congolese female, over 18 years old, outer East London)

Graffiti was also seen as an ineffective means of expression:

I wouldn't do graffiti because that's not gonna get yourself heard... 
Disillusionment and discouragement about participation were largely the result of perceptions of ineffectiveness of any kind of social action:

\section{Participant 2}

My geography teacher was a racist... so there was more than 12 black people... and we were sitting at the back row in the class room ... and one of them was making a lot of noise... So he got fed up and he turned around and he said to him 'oy shut your mouth, you...dark child... stop making noise... we're not back in the Ghetto..'

\section{Participant 3}

That's stereotyping.

\section{Participant 2}

I just said to him 'you're out of order'... I just made a formal complaint...but I told you this world is corrupt... he's still teaching there! They even made him head of the Geography Dept...But he is racist...

(Congolese male, Congolese female, under 18 years old, North London)

... But then one reason I why kind of felt bad is because I thought like these people are coming and taking their time and nothing was going to happen... and that kind of crushes someone's spirit if you... gonna keep going out and you gonna keep doing stuff...

(Congolese female, over 18 years old, outer East London)

However, in marked contrast to both conventional and non-conventional forms of participation, the Congolese youth considered church membership and participation to be very important, rewarding in both spiritual and practical terms:

... and when we got our first payment... in our culture when you go your first payment you give something to you parents... and you put a large sum in the church... that exactly what I have done after that, like a week later, they called me to the office and they gave me a contract to me only... I thought it was nothing... but I then I thought maybe that was... because most of the money that I get I put aside for my ticket to go Nkamba or I 
put in the church... I am not really a person that buys a lot of things. When I thought back I thought it might be because of that...It might be...

(Congolese male, under 18 years old, North London)

... The amount of time... in the 6 or 7 hours that we are on Sunday (in the Church), do you know how much goes on outside...? That we miss... in a good way... Because you could got stabbed, you could have been raped... everything could have happened to you...

(Congolese female, under 18 years old, North London)

Furthermore, these Congolese youth argued that, thanks to religion, they could address or even resist racism and sexism, overcome stereotypes and progress professionally:

Yeah religion, definitely... I think religion at the moment is my... I wouldn't say its religion... I don't believe it's religious, I believe it's spiritual, reason being cos I think religion rules and... with me it's not rules, it's my relationship with God and my relationship with Christ... and I think that does push me a lot to do certain things. Mainly because when I hear people say 'yes, you are a black female, that's what gonna stop you, you are a black female' but yeah, that kind of puts you down, but I think my faith is the only thing that keeps me going... My faith is the only thing that keeps me... like pushing on... My faith is the only thing that would tell me apply for that job because you are worth it... do you get me?

(Congolese female, over 18 years old, outer East London)

For some of the Congolese participants, charity organisations were of uncontested effectiveness; these youth believed that by engaging with these organisations they were helping disadvantaged groups of society and helping to achieve the goals of these organisations:

Yes, cos I like to give back to society, I think it's important for us to join a charity... to do something...if we can do something, then by all means, come on, let's do it...

(Congolese male, over 18 years old, outer East London) 
Well, I like to get involved in stuff that help other people...

(Congolese male, over 18 years old, outer East London)

\section{English participants}

Concerning voting, both narratives of effectiveness and narratives of ineffectiveness were presented by the English participants. In marked contrast to the Congolese participants, the narrative of effectiveness for some English participants included the argument that voting is the way to achieve the representation people want, and that some politicians especially at a local level - are honest and keep their promises:

No, not really, some of them speak the truth.....they do stick to some of their policies. Think about Boris Johnson, he said he is getting rid of these bendy buses like....and he got rid of them.

(English female, under 18 years old, South London)

On the other hand, some English youth expressed the same narrative of ineffectiveness about conventional participation that had been expressed by the Bangladeshi and Congolese participants, one which was clearly related to low external efficacy, namely politicians' lack of responsiveness and lack of commitment to their promises. Politicians, or people in power, were portrayed as declaring that they will take into consideration young people's opinions but in the end not keeping their promises. This was attributed either to the difficulty in making real changes in favour of young people or simply to politicians' lack of interest in young people which they tried to cover up due to the social undesirability of such a claim:

Participant 2

I think they say they care because they can't say that they don't care.

Participant 3

I just think they don't care about what young people think...

Participant 4

If they did, I think a lot would be different...

(English females, under 18 years old, South London) 
As far as non-conventional participation was concerned, in contrast to both the Bangladeshi and Congolese participants, the English participants, especially those above voting age, expressed high involvement in different types of non-conventional activities which were legal. One of the recurrent arguments for the effectiveness of group level participation amongst the English participants was belief in the effectiveness of collective action; participation in high numbers was perceived as attracting political attention which could lead to the satisfaction of people's demands:

Not always, because Parliament actually might pay attention one day when there is like near enough half of London to say.

(English female, under 18 years old, South London)

I know, this is on a very large scale, but you know, how they say about Christmas number one, that it is going to be X-Factor or something but then, they started making groups on Facebook to get back... and they won.

(English male, under 18 years old, central London)

However, participation on a large scale bears the danger, according to participants, of becoming a 'trend', which people follow without really knowing the reasons or the implications of their participation. In this case, participation loses its effectiveness for the individual and also for society:

\section{Participant 6}

I don't necessarily know if bigger is better. Because it can sometimes lose its credence. Because... you don't have people jumping on the bandwagon as I said earlier, maybe you ask $10 \%$ of them what the real meaning of them being there is. And some people say ' $\mathrm{Oh}$ I wanted to skip school', 'Or I wanted to get out of work'. And they are not really there for the real issues.

\section{Participant 1}

I think that's what happened with the original Anti-war protest back in whenever it was. This, erm... so many people jumped on the bandwagon, about, 'Oh yeah, I don't want to 
go to school, so I'm going to go on this anti-war protest thing'. It just kind of lost all meaning that it was just a bunch of people skiving off school.

(English females, over 18 years old, central London)

Illegal forms of non-conventional participation were rejected, especially by older female participants. These forms were seen to be ineffective because of their illegality and their low external efficacy:

\section{Participant 2}

I think it's quite ineffective in the end, you get your picture taken, you go on the paper and then that's it.

\section{Participant 5}

Also I think at times it can have a negative effect if they do like ...

\section{Participant 2}

They are breaking the law.

(English females, over 18 years old, West London)

Concerning environmental issues in particular, a narrative of ineffectiveness and a narrative of effectiveness were created in relation to non-conventional forms of participation, the former based on the necessity of global interest and action for issues of such scale, and the latter based on an acknowledgement of the necessity of small gradual changes:

\section{Participant 4}

I don't think it's ever gonna change though, because there are always people out there...

\section{Participant 2}

And we are never gonna do enough, it's just gonna slow down, it's not gonna stop it

\section{Participant 4}

And there is lots of people who actually don't care, however much other people do.

(English females, under 18 years old, South London) 
Every little helps, because of global warming and stuff the world is basically going back to another ice age and it has been said that if we don't change what we are like now, in the next 40 years or more, we could end up going into an Ice Age.

(English female, under 18 years old, South London)

For English participants, the effectiveness of charity organisations concerning issues such as poverty, or social disadvantage, was based on the acknowledgement and reward of these organisations by national institutions. Participants reported being members of a range of charity organisations such as debating groups, social entrepreneurship groups and legal aid groups, founded by educational institutions:

I am in a social entrepreneurship group which is like it's at the university, I was in it as a student and then now that I am working at Imperial I am kind of doing it semi/ just graduated, ....which is about basically coming up with like socially conscious businesses and then there are competitions in England and stuff, in the UK, like we did a business pan-competition and came second at Imperial so we are gonna go forward and do more national competitions on like socially aware businesses basically.

(English female, over 18 years old, Central London)

I have signed up ... it's essentially legal aid but it's done with law students and you can basically your text books and give people not advice but...

(English female, over 18 years old, Central London)

\section{Discussion}

The results of the present study revealed: (a) the important role of perceived effectiveness in young people's decisions to participate both civically and politically; (b) differences in judgements of effectiveness across ethnic groups; and (c) differences in the specific reasons that were given for judgements of effectiveness, not only as a function of ethnicity, gender and age, but also as a function of the type of participation involved (conventional vs. non-conventional vs. civic).

Ethnic group differences were marked in relationship to conventional forms of participation such as voting (Saggar, 1998; Zukin et al., 2006). In general, very low levels of effectiveness were ascribed to conventional participation by the Bangladeshi and Congolese 
participants, and in this respect, they were noticeably different from the English participants. A further significant ethnic group difference was the role that religion and church membership played in the lives of the Congolese youth, who talked about the effectiveness of religion and church membership in both spiritual and practical terms (Stepick \& Stepick, 2002; Eade \& Garbin, 2007; Wahlström, 2010). Their emphasis on the practical benefits of religion and the church to which they belonged is especially noteworthy. In addition, the issue of trust was made salient especially by the minority individuals (Kelly, 2009), who developed both negative and positive narratives around it, while trust was only mentioned by the English majority young people in a positive way. English young people appeared to be more trustful of the processes followed in their country both in civic and political terms than ethnic minority young people were.

The importance of the intersectionality based on ethnicity, age and gender when studying perceptions of effectiveness in civic and political participation was very salient in relationship to non-conventional forms of participation. Breaking the law was an important factor for perceived ineffectiveness especially amongst female participants below voting age and male participants above voting age of an ethnic minority background, while low external efficacy was important especially for participants above voting age. Similarly, older participants, in contrast to younger participants, having had personal experience of participation, argued for the importance of personal enrichment (Menezes, 2003) in civic participation and gave emphasis to the processes followed by charity organisations (Gaskin, 1999; Fenton, Passey \& Hems, 1999), both to increase fundraising and to ensure the distribution of the funds to the people who are in need. Furthermore, religion and culture appeared to be more salient in the female participants' narratives.

Despite these differences, low external efficacy was the main factor that appeared to be driving perceptions of ineffectiveness in most of the young people independently of ethnicity, age or gender, although this characteristic was deployed differently by different groups in relationship to different forms of action. This finding confirms the importance of efficacy for political participation as many authors have argued (e.g., Craig et al., 1990; Delli Carpini \& Keeter, 1996; Klandermans, 1984, 2002; Schulz, 2005; van Zomeren et al., 2008), but it also reveals the need to take into account the specific form of action involved, its target, and the characteristics of the individual involved.

The results of the present study reveal the need to explore in greater depth the role of the perceived effectiveness of political and civic action, and to examine the specific perceptions of and understandings about civic and political participation among different social 
subgroups defined in terms of intersections between ethnicity, age and gender. Given the differences in patterns of judgement and reasoning that were revealed by the present study, such an approach is vital for enabling both researchers and policymakers to avoid making unfounded overgeneralisations about young people's perceptions and understandings of the political and civic spheres. 


\section{References}

Ahmad, N. \& Pinnock, K. (2007). Civic Participation: Potential Differences between Ethnic Groups. London: Commission for Racial Equality.

Braun, V. \& Clarke, V. (2006). Using thematic analysis in psychology. Qualitative Research in Psychology, 3(2), 77-101

Brooks, R. (2009). Young people and political participation: An analysis of European Union policies. Sociological Research Online, 14(1), 7, doi:10.5153/sro.1862.

Craig, S.C., Niemi, R.G. \& Silver, G.E. (1990). Political efficacy and trust: A report on the NES pilot study items. Political Behaviour, 12, 289-314.

Delli Carpini, M.X. \& Keeter, S. (1996). What Americans Know about Politics and Why it Matters. New Haven: Yale University Press.

Eade, J. \& Garbin, D. (2007, November). Reinterpreting the relationship between centre and periphery: Pilgrimage and sacred spatialisation among Polish and Congolese communities in Britain. Mobilities, 2, 423-424.

Fennema, M. \& Tillie, J. (2001). Civic community, political participation and political trust of ethnic groups. Connections, 24, 26-41.

Fenton, N., Passey, A. \& Hems, L. (1999). Trust, the voluntary sector and civil society. International Journal of Sociology and Social Policy, 19 (7), p. 21 - 42

Gaskin, K. (1999). Blurred vision: public trust in charities. International Journal of Nonprofit and Voluntary Sector Marketing, 4, 163-178.

Jensen, L.A. (2010). Immigrant youth in the United States: coming of age in diverse cultures. In L.R. Sherrod, J. Torney-Purta \& C.A. Flanagan (Eds.), Handbook of Research on Civic Engagement in Youth (pp. 425-443). Hoboken, N.J.: John Wiley \& Sons.

Jensen, L.A. \& Flanagan, C.A. (2008). Immigrant civic engagement: New translations. Applied Developmental Science, 12, 55-56.

Joffe, H. \& Yardley, L. (2004). Content and thematic analysis. In D.F. Marks \& L. Yardley (Eds.), Research Methods for Clinical Health Psychology (pp. 56-68). London: Sage.

Kelly C. (2009) In preparation for adulthood: Exploring civic participation and social trust among youth minorities, Youth \& Society, 40, 526-540.

Klandermans, B. (1984). Mobilization and participation: Social-psychological expansions of resource mobilization theory. American Sociological Review, 49, 583-600.

Klandermans, B. (2002). How group identity helps to overcome the dilemma of collective action. American Behavioral Scientist, 45, 887-900. 
Menezes, I. (2003). Participation experiences and civic concepts, attitudes and engagement: Implications for citizenship education projects. European Educational Research Journal, 2 (3), 430-445

O’Toole, T., Lister, M., Marsh, D., Jones, S., \& McDonagh, A. (2003). Tuning out or left out? Participation and non-participation among young people. Contemporary Politics, 9, 45-61.

Pachi, D. \& Barrett, M. (2011). Perceptions of citizenship amongst young people of prevoting and post-voting age in London. Paper presented at the European Conference on Developmental Psychology, 23-27 August 2011, Bergen, Norway.

Penninx, R., Martiniello, M. \& Vertovec, S. (Eds.) (2004). Citizenship in European Cities: Immigrants Local Politics and Integration Policies. London: Ashgate.

Saggar, S. (1998). Race and British Electoral Politics, London : UCL Press

Schulz, W. (2005). Political efficacy and expected participation among lower and upper secondary students. A comparative analysis with data from the IEA Civic Education Study. Paper presented at the ECPR General Conference, 8-10 September 2005, Budapest, Hungary.

Seif, H. (2010). The civic life of Latina/o immigrant youth: challenging boundaries and creating safe spaces. In L.R. Sherrod, J. Torney-Purta \& C.A. Flanagan (Eds.), Handbook of Research on Civic Engagement in Youth (pp. 445-470). Hoboken, N.J.: John Wiley \& Sons.

Simon, B., Loewy, M., Sturmer, S., Weber, U., Freytag, P., Habig, C., Kampmeier, C. \& Spahlinger, P. (1998). Collective identification and social movement participation. Journal of Personality and Social Psychology, 74, 646-658.

Simon, B. \& Ruhs, D. (2008). Identity and politicization among Turkish migrants in Germany: The role of dual identification. Journal of Personality and Social Psychology, 95, 1354-1366.

Stepick, A. \& Stepick, C. D. (2002). Becoming American, constructing ethnicity: Immigrant youth and civic engagement. Applied Developmental Science, 6, 246-257.

Stepick, A., Stepick, C. D. \& Labissiere, Y. (2008). South Florida's immigrant youth and civic engagement: Major engagement: Minor differences. Applied Developmental Science, 12, 57-65.

Torney-Purta, J., Lehmann, R., Oswald, H. \& Schulz, W. (2001). Citizenship and Education in Twenty-Eight Countries: Civic Knowledge and Engagement at Age Fourteen. Amsterdam: IEA. 
van Zomeren, M., Postmes, T., \& Spears, R. (2008). Toward an integrative social identity model of collective action: A quantitative research synthesis of three sociopsychological perspectives. Psychological Bulletin, 134, 504-535.

Verba, S., Schlozman, K.L. \& Brady, H.E. (1995). Voice and Equality: Civic Volunteerism In American Politics. Cambridge, MA: Harvard University Press.

Wahlström, ̊ (2010). Friends, corporate parents and Pentecostal churches: unaccompanied asylum seekers from the Democratic Republic of Congo in London. $\mathrm{PhD}$ Thesis, School of Social Sciences, University of Brunel

Wu, C.-L. (2003). Psycho-political correlates of political efficacy: The case of the 1994 New Orleans mayoral election. Journal of Black Studies, 33, 729-760.

Zani, B., Cicognani, E. \& Albanesi, C. (2012). The perspective of Social and Community Psychology for a model of political and civic participation. Unpublished paper, The PIDOP Project.

Zukin, C., Keeter, S., Andolina, M., Jenkins, K., \& Delli Carpini, M. X. (2006). A New Engagement, Political Participation, Civic Life, and the Changing American Citizen. New York: Oxford University Press. 